\title{
Threats to Gelada Baboon (Theropithecus gelada) around Debre Libanos, Northwest Shewa Zone, Ethiopia
}

\author{
Kassahun Abie ${ }^{1}$ and Afework Bekele ${ }^{2}$ \\ ${ }^{1}$ Department of Wildlife and Ecotourism Management, College of Agriculture and Natural Resource, Wolkite University, \\ P.O. Box 07, Wolkite, Ethiopia \\ ${ }^{2}$ Department of Zoological Sciences, College of Natural Sciences, Addis Ababa University, P.O. Box 1176, Addis Ababa, Ethiopia
}

Correspondence should be addressed to Kassahun Abie; kassahun.abie@wku.edu.et

Received 24 June 2016; Accepted 14 August 2016

Academic Editor: Alexandre Sebbenn

Copyright ( $) 2016 \mathrm{~K}$. Abie and A. Bekele. This is an open access article distributed under the Creative Commons Attribution License, which permits unrestricted use, distribution, and reproduction in any medium, provided the original work is properly cited.

\begin{abstract}
This study was aimed at determining threats to gelada baboon around Debre Libanos, Northwest Shewa Zone, Ethiopia. This was investigated based on questionnaire, informant interview, focus group discussion, and direct observation methods from August 2012 to March 2013. Data were analyzed using descriptive statistics, and responses were compared using chi-square test. Habitat destruction (95\%), livestock grazing (91.67\%), expansion of agricultural land (88.33\%), expansion of invasive species (58.33\%) in the area that reduces the availability and quality of gelada baboon's food, inappropriate investment activity (75\%), and depredation $(66.67 \%)$ were the major threats to gelada baboons in the study area. All these challenges could cause a short and long-term effect on gelada baboon population size and growth rate.
\end{abstract}

\section{Introduction}

The major threats to the biodiversity and wildlife in Ethiopia are unsustainable utilization of natural resources, deforestation, forest fires, land degradation, habitat fragmentation, expansion of invasive species, predation, and overexploitation of species. Among the threats posed to biodiversity and wildlife in Ethiopia, population growth drives the most direct influence and exacerbates the effects of others. Population growth translates into greater pressure on the land and resources to provide for immediate human needs, thereby threatening the ultimate sustainability of the resources [1]. As human population increases, encroachment into natural habitat also increases, resulting in a different form of humanwildlife conflicts [2].

Human-wildlife conflict is not restricted to a particular geographical location; rather, it is common to all areas where wildlife and human population share limited resources [3]. The large areas of Ethiopian lowland and highlands are changed into agricultural and pastoral lands. The vegetation is overused for fuel wood, construction, timber production, and other purposes. Increasing livestock and human population pressure coupled with misappropriate land use has led to massive destruction of wildlife habitat as well as a drastic reduction in numbers. Hence, wildlife resources of the country are now largely restricted to a few protected areas and inaccessible areas [4]. Therefore, wildlife management is crucial for conservation of biodiversity including wildlife. Wildlife management focuses on increasing net benefit for society through purposeful intervention. The interventions can be educational communication to influence beliefs and attitudes, information, training, incentives, and regulations to affect human behavior and wildlife population control [1]

Even though the gelada baboon population is recorded in the Northwest Shewa zone of Oromia Regional State, little is known about the threats to gelada baboon in the area. The intension of this research was to fill this gap and give relevant information about the challenges to gelada baboon conservation for local and regional administration and other conservation organizations. 


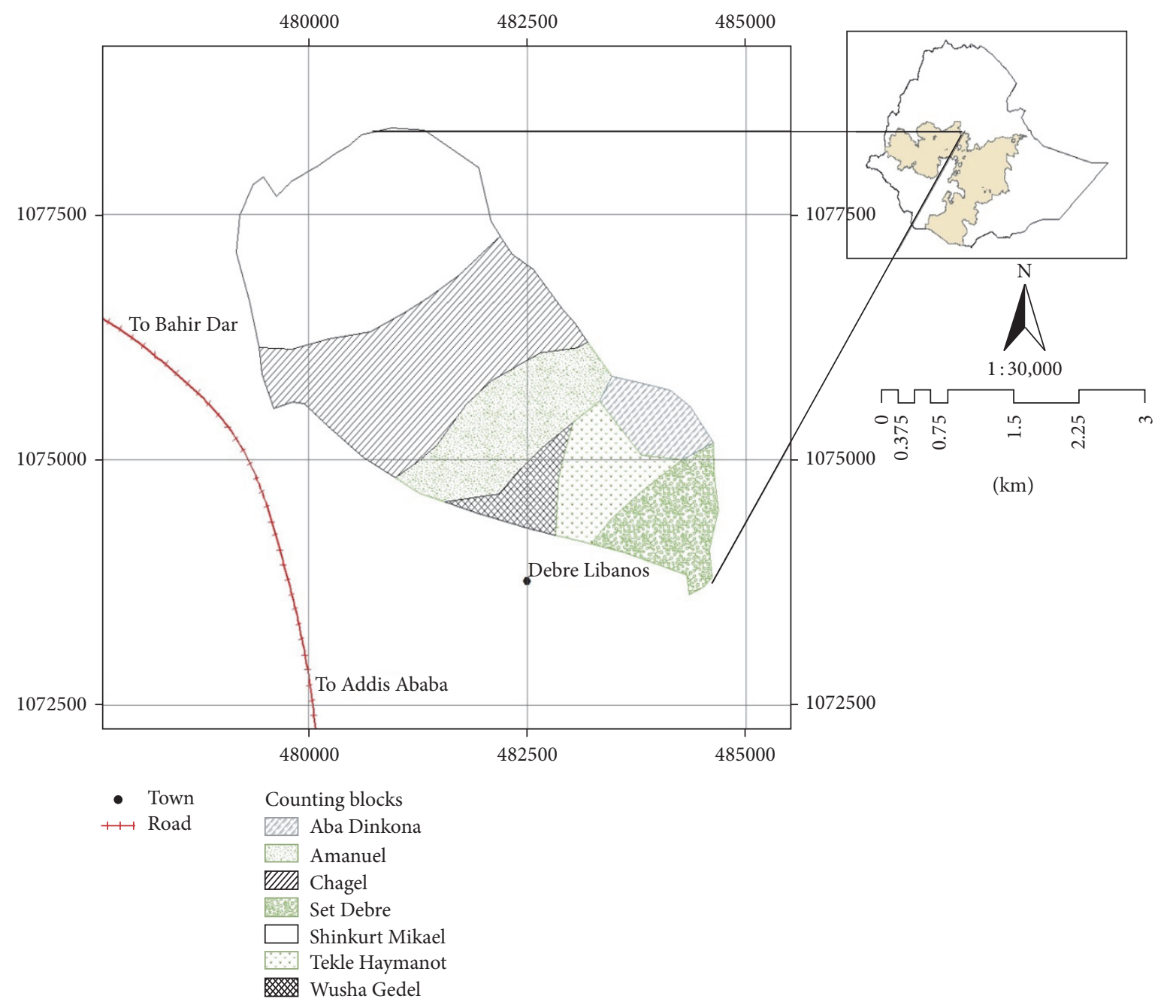

FIGURE 1: Map of the study area.

\section{Material and Methods}

2.1. Study Area. The present investigation was conducted at Debre Libanos area, which is located in the central highlands of Ethiopia. Its geographical coordinates are $9^{\circ} 43^{\prime} 0^{\prime \prime}$ North, $38^{\circ} 52^{\prime} 0^{\prime \prime}$ East. Debre Libanos is found in the Oromia Regional State, within the Northwest Shewa zonal administration (Figure 1). It is located $104 \mathrm{~km}$ away from the capital city, Addis Ababa, in the northwest direction, and $16 \mathrm{~km}$ away from the zone capital (Fiche). The area has extremely steep escarpments leading up to a strip of plateau. It is found in the altitude ranges between 2150 and $2650 \mathrm{~m}$ asl.

It has bimodal rainfall pattern ranging from $800 \mathrm{~mm}$ to $1200 \mathrm{~mm}$ with five months of rain (May-September). The dry season is from December to March. The annual average maximum and minimum temperature of the study area is $23^{\circ} \mathrm{C}$ and $15^{\circ} \mathrm{C}$, respectively.

2.2. Data Collection and Sampling Procedure. The present study was conducted from August 2012 to March 2013. A preliminary survey was conducted in the study area in the first week of August 2012. During this period, the demographic, socioeconomic and environmental condition has been overviewed. Quantitative and qualitative data were collected on the impact of the local people on the gelada baboon around Debre Libanos area.

Data about threats to gelada baboons was collected using informant interviews, questionnaire survey, field observation, and focused group discussion. Data was strengthened through the triangulation of both quantitative and qualitative data. The quantitative data was obtained by means of the questionnaire survey whereas qualitative data was obtained by means of the informant interviews, field observation, and focus group discussion. Field observation was made to collect evidences related to threats to gelada baboons in the study area. Semistructured interview was carried out with key informants. Semistructured interviews are preferred to standardize, control, and easily compare the responses to a question $[5,6]$. One to one interview was employed to get important details about challenges gelada baboons faced. Questionnaire survey was carried out to gain comparable data to allow for quantification. For this matter, semistructured questionnaire was prepared for the target respondents. It was 
developed to collect demographic and socioeconomic information and threats to gelada baboons in the study area.

The sample size was determined by using a method that estimates minimum sample size based on a number of accuracy factors [7]. Hence, the following equation was used to determine the sample size:

$$
n=\frac{\left((P(1-P)) /\left(A^{2} / Z^{2}+(P(1-P)) / N\right)\right)}{R},
$$

where $n=$ sample size required, $N=$ number of people in the population (which in this case is 4, with 800 households), $P=$ estimated variance in population as decimal: 0.3 for $30 \%, A=$ precision desired as decimal: 0.95 for $95 \%, Z=$ at confidence level: 1.96 for $95 \%$ confidence level, $R=$ estimated response rate: 0.8 for $80 \%$.

Accordingly, from the total households $(4,800)$, a total of 60 respondents were selected and the questionnaire was administered. The respondents were selected purposefully based on their ability, awareness, and knowledge to contribute to the overall research objectives. The snowball sampling technique was used as an identification tool. The questionnaire was pretested by a small number of interviews before conducting the actual one among some groups of the population, which is not included in the main sample group to make it more practical. Focus group discussion tool is preferred as, firstly, it helps the discussant to be free to move the conversation in any direction of interest to explore a topic broadly and, secondly, it helps the researcher explore a situation in a short period of time and reinforce questionnaire data [8]. Two FGD were held for the whole study. The group size in each discussion ranged within 9-12 people. The first group was made up of 2 experts of natural resource management from Agricultural and Rural Development Office, 3 experts from wildlife and forest enterprise of the districts, 2 experts from culture and tourism office of the district, and 2 people from kebele governmental administrators, whereas the second group was made up of 5 elders of villages, 3 females from females association, 2 local leaders, and 1 person from the nearby school. Discussants were invited to discuss issues according to their convenience. They have discussed changes, problems, and challenges to conservation of gelada baboons.

2.3. Data Analysis. The data were pooled together, and SPSS software for Windows Evaluation Version 20 was used for statistical analysis using descriptive statistics and chi-square test. Statistical test used was two-tailed with $95 \%$ confidence intervals. The data collected from group discussion and key informants was summarized using a text analysis method and is presented in a description fashion.

\section{Result and Discussion}

Demographic information of respondents is shown in Table 1. Out of the total respondents, $56.7 \%$ were males and $43.3 \%$ were females. There was no significant difference in the number of male and female respondents $\left(\chi^{2}=1.067, \mathrm{df}=1\right.$, $P>0.05)$. The vast majority of respondents were illiterate $(81.7 \%)$ and few were literate $(18.3 \%)$. The majority $(83.3 \%)$ of
TABLE 1: Description of demographic and socioeconomic characteristics of the respondents.

\begin{tabular}{lccc}
\hline Variables & Category & Frequency & Percentage \\
\hline \multirow{2}{*}{ Sex } & Male & 34 & 56.67 \\
& Female & 26 & 43.33 \\
\hline \multirow{2}{*}{ Education } & Literate & 49 & 81.67 \\
& Illiterate & 11 & 18.33 \\
\hline \multirow{3}{*}{ Marital status } & Married & 46 & 76.67 \\
& Single & 9 & 15.00 \\
& Divorced & 5 & 8.33 \\
\hline \multirow{3}{*}{ Occupation } & Farmers & 41 & 68.33 \\
& Government workers & 10 & 16.67 \\
& Traders & 6 & 10.00 \\
& Students & 3 & 5.00 \\
\hline
\end{tabular}

the respondents' ages ranged from 31 to 60 years, while $10 \%$ and $6.7 \%$ of the respondents were less than 30 and older than 60 years, respectively. Out of the total respondents, $76.7 \%$ were married, $15 \%$ were single, and 8.3 were divorced. Most of the respondents were farmers (68.33\%), followed by government workers (16.67\%), traders (10\%), and students (5\%). There is significant difference among occupations of the respondents $\left(\chi^{2}=61.733, \mathrm{df}=3, P<0.05\right)$.

Focus group discussion and interview with local communities, local governmental, and nongovernmental organization officials of Debre Libanos area provided information about the attitude towards conservation and on wildlife and impacts on gelada baboons of the area. Among the interviewed individuals, $89 \%$ had negative attitude, $6.2 \%$ had positive attitude, and $4.8 \%$ had neutral attitude towards the wildlife including gelada baboons of the area. During focus group discussion, most discussants were not happy with the existence of gelada baboons. They considered these wild animals as a limiting factor to improve their livelihood because of the crop raiding problem they cause for local people. The result of this study contradicted with the work of Andarge [9] at Guassa community conservation area and Yihune [10] at Simien Mountains National Park.

The presence of local people in the area leads to human pressure in and around conservation areas and humanwildlife interactions are becoming more common [11]. Many studies in Africa revealed that local people consider most medium and large sized wild animals as a pests to their crops, whereas the attitude of local people towards wildlife is an important element to ensure the long-term survival of wildlife resources [21].

The major identified threats that affect the status of gelada baboons in the study area were habitat destruction, livestock grazing, expansion of agricultural land, expansion of invasive species, depredation, and inappropriate investment. There is insignificant difference among the threats that affect the gelada baboon population in the study area $\left(\chi^{2}=7.872, \mathrm{df}=\right.$ $5, P>0.05)$. The respondents' result on the threats of gelada baboons is presented in Table 2 .

Habitat destruction (95\%) was recorded as the major challenge for existence of gelada baboons in the study area. 

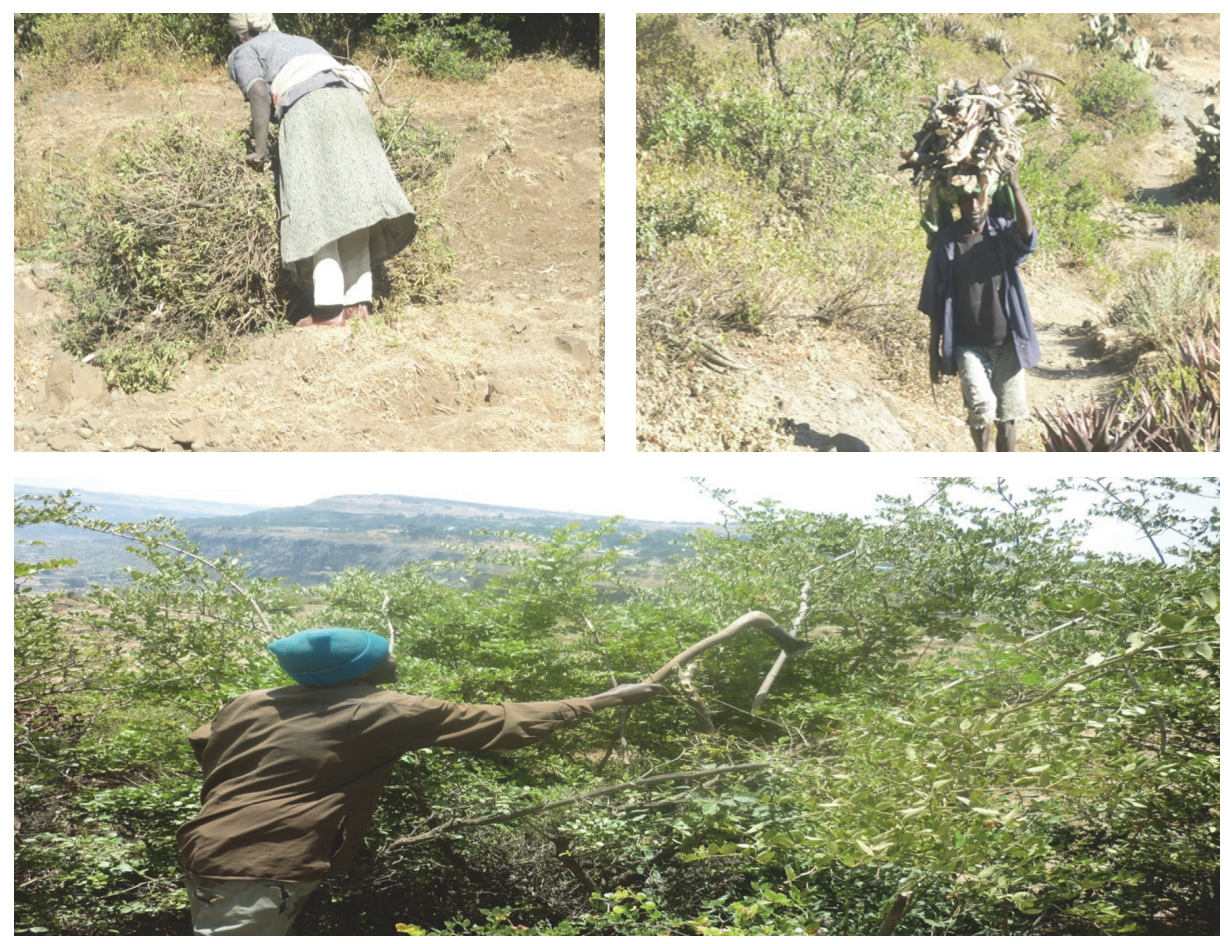

FIGURE 2: Local people cutting trees and collecting firewood.

TABLE 2: Respondents' result on threats to gelada baboons.

\begin{tabular}{lcc}
\hline Threat to gelada baboons & Frequency & Percentage \\
\hline Habitat destruction & 57 & 95 \\
Livestock grazing & 55 & 91.67 \\
Expansion of agricultural land & 50 & 88.33 \\
Inappropriate investment & 45 & 75.00 \\
Depredation & 40 & 66.67 \\
Expansion of invasive species & 35 & 58.33 \\
\hline
\end{tabular}

The increase in human population has resulted in more demand for food, farmland, and other natural products. This has also resulted in constriction of ranges and led to change on composition and structure of the habitat [12]. In the tropical developing countries, protected areas are continually under threat from growing human population [13]. Local people of the study area occupied the new land for different purposes. Cutting of trees for fuelwood, charcoal production, construction of house and fence, and timber production were common practices in the entire study area. Many local people were observed when they were cutting and collecting firewood from the bushland habitat of the study area (Figure 2). In developing countries like Ethiopia, 75\% of deforestation and habitat loss was caused by local people for fuel wood collection purpose [14]. Tree cutting resulted in deterioration of the vegetation cover. This minimizes the feeding ground and mating site of the wild animals [15].

Respondents (91.67\%) revealed that livestock grazing was a major challenge for gelada baboons. Livestock of the local people graze and compete with the gelada baboons (Figure 3).

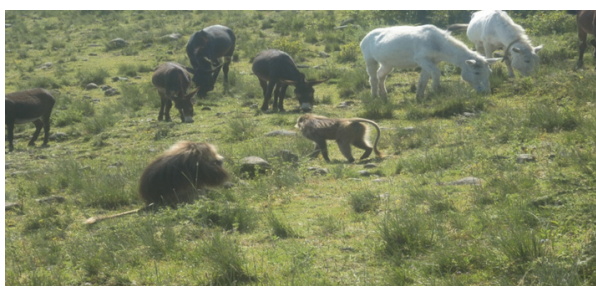

FIGURE 3: Domestic animals competing with gelada baboons.

The most commonly observed domestic animals in the study area were cows, oxen, sheep, goats, donkeys, and mules. The presence of excess number of livestock causes direct competition for food with gelada baboons and other wildlife in the area (Figure 3). High number of cattle and scarcity of grazing land made the local people use even difficult cliffy area for grazing and agriculture. This has been observed during field observation in the study area and confirmed by the local people during focus group discussion. The same result was supported by Aramde et al., 2011 [16], and Chanie and Tesfaye, 2015 [17], where livestock grazing deteriorates wildlife habitats and diminishes the population size. Frequent and extreme disturbances can radically alter an ecosystem and change it to a different state. Persistent overgrazing can make the habitat bare [18].

$88.33 \%$ of the respondents reported agricultural land expansion as major threat to gelada baboons. The local people farm mainly maize, teff, and other cereal crops. People cultivated crops by using even the infertile and cliffy areas which are also habitat for gelada baboons. Gelada baboons moved 
to the farmers land and consume these crops. So, the local people chased gelada baboons away from their farmland by shouting, whistling, and throwing. Conflict becomes more serious in tropics and developing countries where agriculture and livestock rearing are important parts of local communities livelihood $[19,20]$. Human population growth increases demand for land, and it results in restriction of animals to small areas and direct competition with local communities [21].

$75 \%$ of the respondents reported inappropriate investment as threat to gelada baboons. The study area has very attractive landscape with different natural and man-made tourism potentials, such as Debis cave, mountainous nature essential for paragliding, wild animals including the endemic gelada baboon, the historical Debre Libanos monastery, and other tourist attractions. The presence of these tourism potentials made the area ideal for hotel and tourism development. However, cattle and bee rearing within the habitat of gelada baboons is practiced by investors, which was unproductive and also threatened the gelada baboon population. Studies by Ayalew, 2009 [22], and Beyene, 2010 [23], also reported that agricultural expansion and habitat degradation due to investment and developmental activities threaten the population of gelada baboon.

Depredation (66.67\%) was reported as a threat to gelada baboons by respondents. The natural enemies of gelada baboons are leopard, hyena, jackals, servals, and foxes that are present in the area. Even though predation is a natural phenomenon, sometimes it becomes a major threat for animals when its rate and frequency are unbalanced. The other threat for gelada baboons of the study area was domestic dogs. They were observed chasing infant gelada baboons during the field observation. This phenomenon was also revealed by the discussants of the focus group discussion. This will cause stress and instability in the population, and in the long run this may reduce the population size and growth rate. The dynamics of predation, whether by natural predators or by humans, affects prey species [24]. Therefore, the conservation threat to a species, particularly due to predation, depends on the ecosystem in which it is found.

Expansion of invasive species (58.33\%), especially Eucalyptus globulus, is a major problem in the study areas. Eucalyptus globulus is a cash crop for local people of the study area. They plant this species to get money, fuelwood, and other benefits, where its area coverage is increasing from time to time. Due to the aggressive nature of this species, other plant species which are source of food for gelada baboons and other herbivores could not grow sustainably in the study area. The discussants reported this seriously. Exotic species are of special management concern because they can threaten other species. Invasive species could cause the extinction of numerous mammals, birds, and invertebrates $[25,26]$. Overdisturbances are often the underlying causes for invasions of exotic species that can take over and maintain new states [27]. Invasive species can result in indirect interactions through hyperpredation, apparent competition, and mesopredator release. These can produce unexpected consequences.

Generally, overgrazing, habitat destruction, and agricultural land expansion, inappropriate investment, and depredation were reported as primary threats to gelada baboons. These human activities resulted in habitat disturbance and decrease in abundance and diversity of wildlife due to destruction of habitat and competition on foraging. Similarly, a study of Ashenafi and Leader-Williams [28] reported that livestock grazing from nearby villages and local community used firewood more frequently in protected areas. The major problem facing protected areas today is the increase in human settlement of adjacent lands and the unauthorized harvesting of resources within the protected areas in Africa (Newmark et al.) [29]. The heaviest impact on primates is likely to be human activities. Construction and the expansion of cities followed by the rapid growth of economy of many countries make it difficult for the species [20]. Many primates are facing a variety of anthropogenic problems due to deforestation and extensive use of their habitats for agricultural activities and settlement [30].

\section{Conclusion and Recommendation}

Habitats of the wildlife are destructed for agriculture; this resulted in lack of enough space, food, and other resources for survival of wildlife. Gelada baboons and local communities use the same habitat and compete for resources. The requirements of wildlife overlap with the people in the area. This causes conflict between local people and gelada baboons. Gelada baboons consumed the crop of local people, and local people also chased gelada baboons. This problem became severe during the wet season in which the local peoples' land was covered with cash crops. As a result, the attitude of most of the local people towards gelada baboons is negative. So, protection and safeguarding of gelada baboon population in the study area demand a great effort.

Fire wood collection, commercial timber production, agricultural and grazing land expansion, and illegal hunting have significant impact on accelerating degradation of habitats and cause competition between wild and domestic animals for resources. These problems are highly affecting the status of gelada baboons in Debre Libanos.

Recommendations. The following points are suggested to reduce the problems and conserve the population of gelada baboon properly:

(i) Effective conservation measures should be taken through an extension work to create public awareness among the local community. This will help the local people to appreciate the benefits of natural resources. It is important to integrate the use of full indigenous knowledge and modern conservation systems to develop a deeper understanding of the species and their ecosystems.

(ii) Local people should participate in the process of resolving the existing challenges in order to foster positive outlook towards wildlife.

(iii) Implementation of rural development should be designed to move the local people to the buffer zone to reduce human activities in habitats of wildlife and the 
movement of wildlife from their habitats to farming lands.

(iv) Livestock grazing and other human activities that degrade the natural habitats of wildlife should be strictly reduced by developing implementing rules and regulations.

(v) Stakeholders should work together to reduce human encroaching in wildlife habitats and relocate agricultural activities out of wildlife ranges.

(vi) Debre Libanos area has great potential for tourism. Investors should be encouraged to open hotels, restaurants, and lodges in the area. Brochures, posters, and maps should be prepared to promote potential tourist attraction in order to generate money from tourists.

\section{Competing Interests}

The authors do not declare any conflict of interests.

\section{Acknowledgments}

The authors would like to thank Addis Ababa University, Madda Walabu University, and Horn of Africa Regional Environmental Center and Network (HoA-REC/N) for financial support. The authors are also grateful to the local communities of Debre Libanos and Derbre-Libanos District Agricultural and Rural Development Office for providing necessary information to accomplish this work.

\section{References}

[1] IBC, Ethiopia Biodiversity and Tropical Forests 118/119 Assessment, IBC, Addis Ababa, Ethiopia, 2008.

[2] C. M. Hill, "Conflict of interest between people and baboons: crop raiding in Uganda," International Journal of Primatology, vol. 21, no. 2, pp. 299-315, 2000.

[3] M. O. Ogada, R. Woodroffe, N. O. Oguge, and L. G. Frank, "Limiting depredation by African carnivores: the role of livestock husbandry," Conservation Biology, vol. 17, no. 6, pp. 1521-1530, 2003.

[4] J. C. Hillman, Ethiopia: Compendium of Wildlife Conservation Information. Volume I, NYZS and EWCO, Addis Ababa, Ethiopia, 1993.

[5] T. L. Burton and G. E. Cherry, Social Research Techniques for Planners, George Allen a Unwin, London, UK, 1970.

[6] M. Finn, M. Elliott-White, and M. Walton, Tourism and Leisure Research Method, Longham, London, UK, 2000.

[7] J. Watson, How to Determine a Sample Size, Penen State Cooperative Extension, University Park, Pa, USA, 2001, http://ucanr .edu/sites/CEprogramevaluation/files/143304.pdf.

[8] W. M. K. Trochin, The Research Methods Knowledge Base, Cornell University Press, New York, NY, USA, 2003.

[9] E. Andarge, Human-wildlife conflict involving Ethiopian Wolf (Canis simensis) and gelada baboon (Theropithicus gelada) around Guassa community conservation area, North Shoa, Ethiopia [M.S. thesis], Addis Ababa University, Addis Ababa, Ethiopia, 2010.
[10] M. Yihune, Human-wildlife (Gelada Baboon and Ethiopian Wolf) conflict in and around the Simien Mountains National Park [M.S. thesis], Addis Ababa University, Addis Ababa, Ethiopia, 2006.

[11] G. Corti, E. Fanning, S. Gordon, R. J. Hinde, and R. K. B. Jenkins, "Observations on the puku antelope (Kobus vardoni Livingstone, 1857) in the Kilombero Valley, Tanzania," African Journal of Ecology, vol. 40, no. 2, pp. 197-200, 2002.

[12] A. J. Meduna, A. A. Ogunjinmi, and S. A. Onadeko, "Biodiversity conservation problems and their implications on ecotourism in Kainji Lake National Park, Nigeria," International Journal of Sustainable Development, vol. 10, no. 4, pp. 59-73, 2009.

[13] G. Wynne, Conservation Policy and Politics, Oxford University Press, New York, NY, USA, 1998.

[14] FAO, Global Forest Resources Assessment, Food and Agriculture Organization of the United Nations, Rome, Italy, 2000.

[15] T. Kumssa and A. Bekele, "Human wildlife conflict in senkele Swayne's hartebeest sanctuary, Ethiopia," Journal of Experimental Biology and Agricultural Sciences, vol. 1, no. 1, 2013.

[16] F. Aramde, M. Girma, and B. Tsegaye, "Spatial distribution and habitat preferences of selected large mammalian species in the Nechsar National Park (NSNP), Ethiopia," Nature and Science, vol. 9, no. 3, pp. 80-90, 2011.

[17] S. Chanie and D. Tesfaye, "Threats of biodiversity conservation and ecotourism activities in Nechsar National Park, Ethiopia," International Journal of Biodiversity and Conservation, vol. 7, no. 3, pp. 130-139, 2015.

[18] X. B. Wu, T. L. Thurow, and S. G. Whisenant, "Fragmentation and changes in hydrologic function of tiger bush landscapes, south-west Niger," Journal of Ecology, vol. 88, no. 5, pp. 790-800, 2000.

[19] T. A. Messmer, "The emergence of human-wildlife conflict management: turning challenges into opportunities," International Biodeterioration \& Biodegradation, vol. 45, no. 3-4, pp. 97-102, 2000.

[20] Y. Hamada, S. Malaivijitnond, P. Kingsada, and P. Bounnam, "The distribution and present status of primates in the Northern Region of Lao PDR," Natural History Journal of Chulalongkorn University, vol. 7, pp. 161-191, 2007.

[21] K. S. Siex and T. T. Struhsaker, "Colobus monkey and coconutsia study of perceived human-wildlife conflicts," Journal of Applied Ecology, vol. 36, no. 6, pp. 1009-1020, 1999.

[22] Y. Ayalew, Population status, distribution and ecology of gelada baboon (Theropithecus gelada) in Azwa and Arego, South Wollo, Dessie, Ethiopia [M.S. thesis], Addis Ababa University, Addis Ababa,Ethiopia, 2009.

[23] H. Beyene, Population estimate and structure of the gelada baboon in the Guassa community conservation area, central Ethiopia [M.S. thesis], Addis Ababa University, Addis Ababa, Ethiopia, 2010.

[24] F. Courchamp, M. Langlais, and G. Sugihara, "Cats protecting birds: modelling the mesopredator release effect," Journal of Animal Ecology, vol. 68, no. 2, pp. 282-292, 1999.

[25] M. Serena, Reintroduction Biology of Australian and New Zealand Fauna, Surrey Beatty \& Sons, Chipping Norton, Australia, 1994.

[26] I. A. E. Atkinson, "Introduced mammals and models for restoration," Biological Conservation, vol. 99, no. 1, pp. 81-96, 2001.

[27] P. M. Vitousek, C. M. D’Antonio, L. L. Loope, and R. Westbrooks, "Biological invasions as global environmental change," American Scientist, vol. 84, no. 5, pp. 468-478, 1996. 
[28] Z. T. Ashenafi and N. Leader-Williams, "Indigenous common property resource management in the Central Highlands of Ethiopia," Human Ecology, vol. 33, no. 4, pp. 539-563, 2005.

[29] W. D. Newmark, D. N. Manyanza, D. G. M. Gamassa, and H. I. Sariko, "The conflict between wildlife and local people living adjacent to protected areas in Tanzania: human density as a predictor," Conservation Biology, vol. 8, no. 1, pp. 249-255, 1994.

[30] G. Cowlishaw and R. Dunbar, Primate Conservation Biology, University of Chicago Press, Chicago, Ill, USA, 2000. 

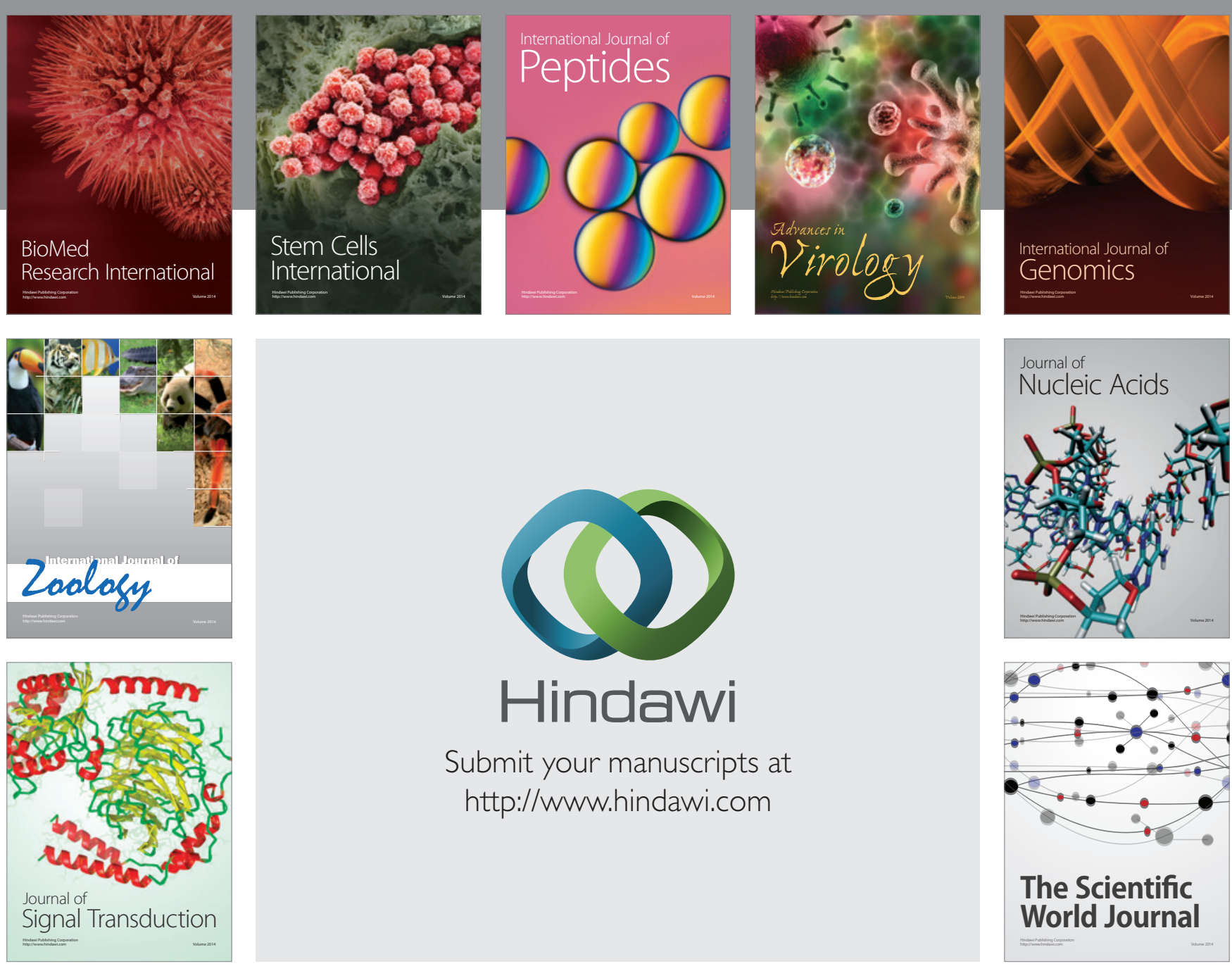

Submit your manuscripts at

http://www.hindawi.com
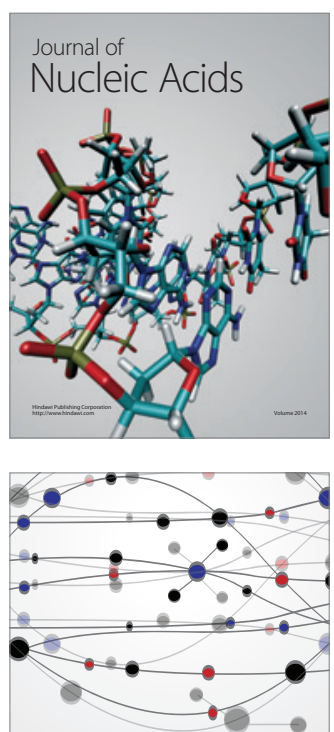

The Scientific World Journal
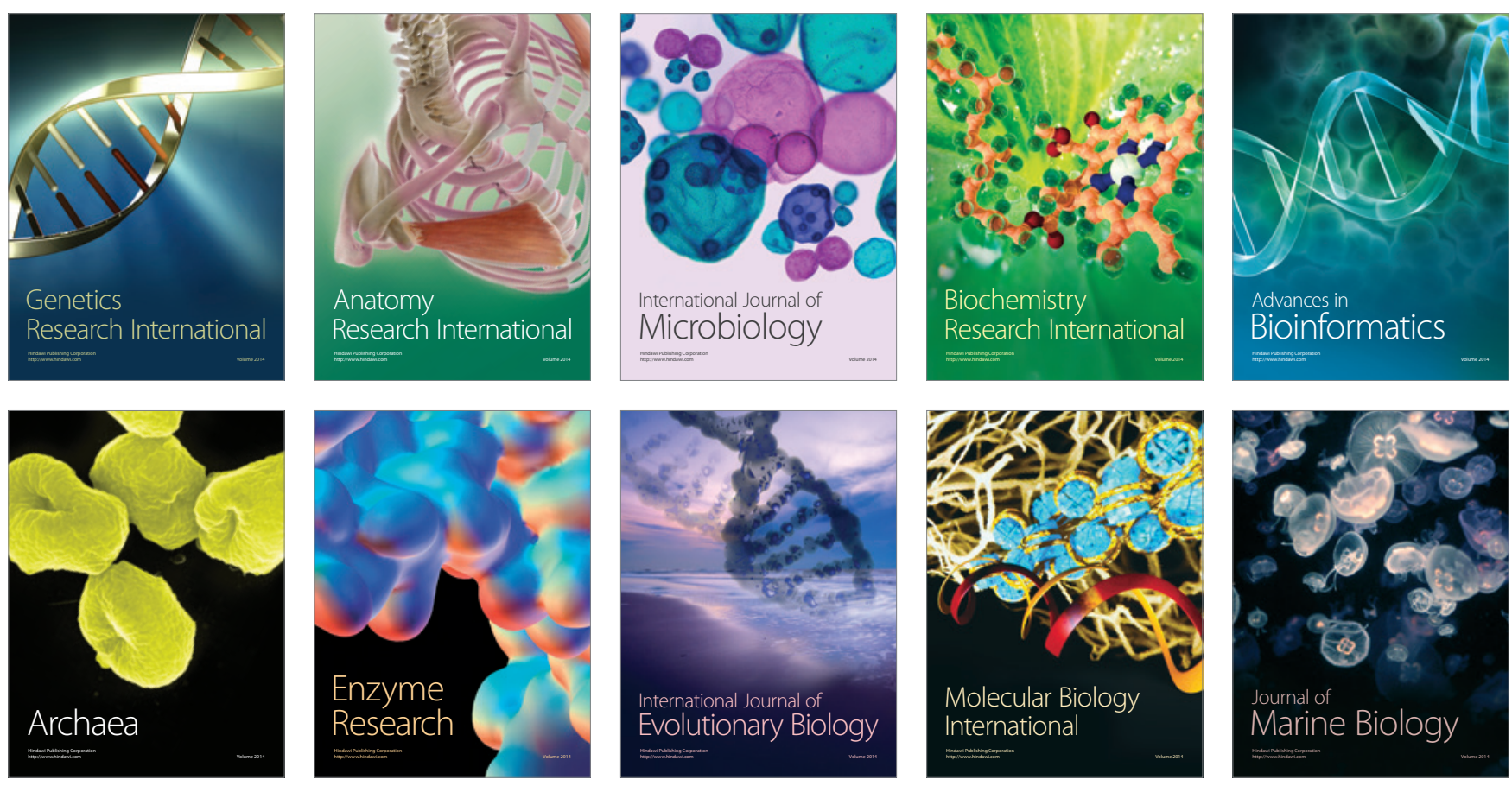